\title{
Evaluating the Impact of the Indian Supreme Court Judgment on Sex-Selective Abortion
}

\author{
By Sital Kalantry and Arindam Nandi
}

\section{Introduction}

Lawyers bring public interest litigation cases ("PIL") to the Indian Supreme Court seeking many different types of remedies, including to prevent the construction of power plants that may damage the environment or to prevent violations of rights of a group of people. The Indian Supreme Court (the "Supreme Court" or "Court") sometimes responds by creating guidelines like what the executive branch might do. But in many PIL cases, litigants are not asking for the creating of new rules, but instead they are simply asking the Supreme Court to encourage the government to amend, implement, and enforce laws that already exist.

In this chapter, we investigate one such case-- the public interest litigation bought by the Center for Enquiry into Health and Allied Themes ("CEHAT"), Mahila Sarvangeen Utkarsh Mandal ("MASUM"), and Sabu George in 2000. These public interest litigants were concerned about the rate of selective abortions of fetuses when the future biological sex of the child was determined to be female. Starting in the 1980s ultrasound machines became more widely available in India and this allowed families to detect the future biological sex of their children and some women chose to abort fetuses when the future sex was predicted to be female. To curb this practice the government had passed a law that became effective in 1996 to prevent medical professionals from giving information to pregnant women about the future sex of their children.

The public interest litigants claimed that the law had not been implemented by the Union and State governments of India. The Supreme Court kept jurisdiction of the case for three years until 2003. During this time it asked for various reports from State governments and prodded the Union government to amend and strengthen its anti-sex determination legislation.

Defining success broadly, it appears that the Supreme Court's intervention was successful - the Union government did indeed amend and strengthen the law. We observe this through the dialogue in Supreme Court hearings with relevant stakeholders and also by examining the discussions in the Indian Parliament about the Supreme Court's orders in this case. Of course, Parliament may have amended the law even without Supreme Court intervention.

However, from a narrow measure of success, the Supreme Court's orders in this case were an utter failure. The ultimate goal of the litigants was to decrease abortions of female fetuses, which they hoped to do by encouraging the Supreme Court to push the Union governement to amend the law to close loopholes and to push State governments to implement the existing law. But, according to our data, the rate of abortions of female fetuses did not decrease during the time the Supreme Court held a number of hearings on 
the case (2000 to 2003) and did not decrease even after the amendments were made to the anti-sex determination law in 2002. On the contrary, the number of female births decreased every year.

Simply referring to the Indian Census data makes it abundantly clear that that sex ratios (the number of girls to boys born in any given time period) decreased from 2001 to 2011. What is unique about the data set we utilize is that it observes year-by-year variation to track the impact from the initiation of the public interest litigation and immediately after the 2003 decision when the court issued its final order in the case. Thus, while the Indian Census will show the change over a period of 10 years, our data can be used to determine whether there were any improvements during the shorter period of time that the Supreme Court had jurisdiction over the case and year-by-year after the enactment of amendments to the anti-sex determination law in 2002. Moreover, the Indian census only reports the sex ratio of children from birth to six years of age. Our data set consists of birth data, which would be more immediately sensitive to increased enforcement efforts for example.

We conjecture that when the Supreme Court intervenes to change deep-seated cultural desires such as the desire for many families who want to have at least one male-child, it may be less successful than when it attempts to intervene in matters that do not relate to deeply held personal views of many people. In addition, given that much of the illegal behavior that the Supreme Court wants to curb takes place outside of the scrutiny of the public view, the law is inherently difficult to enforce.

In Section I, we describe the origin of the Indian sex ratio crisis. We then detail the responses of Parliament and the Indian Supreme Court to the excess of males and shortage of females in Section II. In Section III, we describe the sex ratio trends over time and geography in India. Our analysis of the impact of the public interest litigation is in Section IV. The final section (Section V) examines the causes of the sex ratio crisis and explains why the Indian Supreme Court judgment has not achieved results.

\section{The Indian Sex Ratio Crisis Begins}

In the 1970s, amniocentesis technology-meant to diagnose genetic abnormalities, but also capable of determining the sex of a fetus-became available in India. Ironically, the All India Institute of Medical Sciences, the country's most prestigious medical school, was the first to offer these tests at its government teaching hospital. Other government hospitals soon followed suit. While the technology was meant to identify genetic abnormalities in a fetus, doctors also used the tests to identify the sex of the fetus and would offer an abortion if the sex was not what the mother desired. ${ }^{1}$

The doctors performing the sex-selective abortions justified them on population control grounds. Indeed, population control is arguably a more important goal in India today than it was then. India has only 2.5 percent of world's land and yet

${ }^{1}$ Mara HVistendahl, UnNATURAL SELECTION 80 (2011). 
must accommodate and feed 17 percent of the world's people. ${ }^{2}$ The population density of India is 377.7 inhabitants per square kilometer compared to only 142.9 in China and 31.85 in the United States. ${ }^{3}$

The doctors who first began performing sex detection tests published an article in Indian Pediatrics explaining that they had conducted trials using amniocenteses for sex determination and found that "seven of the eight patients who had tests carried out primarily for the determination of sex of the fetus" aborted their female fetuses. ${ }^{4}$ In the past, American foundations actively supported population control efforts in India, including sex-selective abortions. ${ }^{5}$ In 1978, the use of amniocenteses for purposes of sex determination was banned in government hospitals, but private clinics emerged to fill the growing demand. ${ }^{6}$

Given that amniocenteses involves the removal of amniotic fluid and a laboratory in which the testing must be conducted, these tests were mostly available in cities and only affordable for middle-class or rich people. A new technology, however, changed financial and physical access dramatically: the ultrasound.

By the mid-1980s, many clinics in the capital city of Delhi offered prenatal ultrasound exams. ${ }^{7}$ With a growing middle class and increasing access to ultrasound machines used to detect the sex of the fetus, more abortions occurred, and the sex ratio became further male-skewed. ${ }^{8}$

In the late 1980s, offensive advertisements promoting sex determination tests were commonly visible in India. Commentators often point out that advertisements would state, "Pay 500 rupees now and save 50,000 (in dowry) later." 9 In the state of Haryana, the sex ratio dipped as low as 879 women per 1000 men. ${ }^{10}$ Indian feminists quickly took notice.

${ }^{2}$ Hrishikesh D. Vinod, Newborn Sex Selection and India's Overpopulation Problem, 4 MOD. ECON. 102, 103 (2013).

${ }^{3}$ Id.

${ }^{4}$ MARA HVISTENDAHL, UNNATURAL SELECTION 81 (2011).

${ }^{5}$ Id. at 82-89 (2011).

6 The LAWYER's COLleCtive: Women's Rights Initiative, PRE-CONCEPTION \& PRENATAl Diagnostic TeChNiQues ACT:A USERS GuIDE TO THELAW 1 (Indira Jaising ed., 2004).

${ }^{7}$ Mara HVistendahl, UnNatural SElection 49 (2011).

${ }^{8}$ See ChristopheZ. GuIlmoto, Characteristics of SEX-RATIO IMbAlANCE IN INDIA, AND FUTURE SCENARIOS 4-8 (2007), available at

http:/www.unfpa.org/gender/docs/studies/india.pdf.

${ }^{9}$ Missing Sisters, ECONOMist, April 17, 2003.

${ }^{10}$ Sex Ratio in India, CENSUS 2011, http:// www.census2011.co.in/sexratio.php (last visited Oct. 4, 2013). 


\section{Parliament and the Indian Supreme Court Re sponse}

\section{Parliament Bans Sex Determination (1994)}

Unlike in the United States where the push to ban sex-selective abortion is rooted in the anti-abortion movement, India's movement to curb it was initiated by feminists. ${ }^{11}$ In 1982, a group of women's organizations protested to demand a complete ban on sex determination tests. ${ }^{12}$ In Mumbai, a group called the Forum Against Sex Determination and Sex Pre-Selection was created in 1985. ${ }^{13}$ These groups were explicit in their goal- they did not want to place restrictions on abortion access, but instead demanded that medical professionals be prohibited from telling patients the sex of their fetus. ${ }^{14}$ The state government of Maharashtra, where Mumbai is located, passed legislation to ban sex determination tests in 1988 before any national legislation was passed. ${ }^{15}$

Six years later, in 1994, the Government of India enacted the Pre-Natal Diagnostic Techniques (Regulation and Prevention of Misuse) Act (PNDT). This law, which came into effect in 1996, prohibited the use of techniques (such as ultrasounds and amniocentesis) to determine the sex of the fetus after conception.

\section{Public Interest Litigation in the Supreme Court Commences (2000) and the final Supreme Court Judgment (2003)}

Arguing that national and state governments did not take necessary measures to enforce the PNDT, advocates brought a petition to the Supreme Court of India using a mechanism called public interest litigation whereby people without

11 See generally Sital Kalantry, Sex Selection in the United States and India: A Contextualized Feminist Approach, 18 UCLA J. Int'l L. \& Foreign Aff. 61 (2013); Sital Kalantry, Sex-Selective Abortion Bans: Anti-Immigration or Anti-Abortion?, 16 Geo. J. Int'l Aff. 140 (2015).

12 Mary John, U.N. Population Fund (UNFPA), SeX Ratios and Gender Biased SeX SElection History, Debates AND Future DiReCtions 8 (2014), available at http:/asiapacific.unfpa.org/webdav/site/asiapac ific/shared/Publications/2014/Sex-Ratiosand-Gender-Biased-Sex-Selection.pdf.

${ }^{13}$ Mary John, U.N. Population Fund (UNFPA), SeX Ratios and Gender Biased SeX SELECTION HISTORY, DEBATES AND FUTUREDIRECTIONS 8 (2014), available at http://asiapacific.unfpa.org/webdav/site/asiapacific/shared/Publications/2014/Sex-Ratiosand-Gender-Biased-Sex-Selection.pdf.

${ }^{14}$ Bijayalaxmi Nanda, Campaign Against Female Foeticide: Perspectives, Strategies and Experiences, in SEX-SELECTIVE AbORTION IN INDIA:GENDER, SOCIETY AND NEW RePRoductive TeChNOLOGIES 361 (Tulsi Patel ed., 2007).

${ }^{15}$ Bijayalaxmi Nanda, Campaign Against Female Foeticide: Perspectives, Strategies and Experiences, in SEX-SELECTIVE AborTION IN INDIA:GENDER, SOCIETY AND NEW REPRODUCTIVETECHNOLOGIES 361 (Tulsi Patel ed., 2007). 
standing are able to bring cases directly to the Supreme Court to enforce social justice issues. ${ }^{16}$ In September 2000, the Center for Enquiry into Health and Allied Themes (CEHAT), Mahila Sarvangeen Utkarsh Mandal (MASUM), and Sabu George argued to the Indian Supreme Court that the government had failed to implement the PNDT. ${ }^{17}$ The petitioners asked, among other things, that appropriate authorities be appointed at the state and district levels to monitor compliance with the PNDT.

The Supreme Court issued several interim orders with very specific directions to the Union government and State governments to facilitate implementation of the Act. ${ }^{18}$ Through an examination of the numerous orders, it appears that the Supreme Court was in dialogue with the State governments ${ }^{19}$ and Union government. First, it is ordering State governments to submit detailed reports about its compliance efforts. For example, on April 30, 2002, the Court asked several states to fill affidavits within 15 days reporting a number of things, including why they failed to seize ultrasound machines that were not properly registered pursuant to the PNDT. Second, it is drawing attention to the issues and failure of implementation. The Court notes that "there is a total slackness by the administration in implementing the Act." 20 Third, it asks the body that was appointed pursuant to the PNDT to propose amendments to that PNDT to include newer technology and new methods that can be used to sex select that was not previously included in the prohibition. ${ }^{21}$

Through the course of the three years within which it kept jurisdiction in the case, its interventions served to remind the Union and State governments about the importance of curbing sex selection, about its lack of implementation, and the need for amendments to the PNDT. The Supreme Court kept at this task even though many State governments failed to comply with the Court's requests.

Indeed, in one of his orders in the case, Justice Shah laments that "it appears that the directions issued by this Court are not complied with." 22

In 2003, the Indian Supreme Court issued its final judgment in the case. It repeated many of the recommendations that it had already issued to the various

16 INDIA CONST. art. 32

${ }^{17}$ Centre for Enquiry into Health and Allied Themes (CEHAT) v. Union of India, (2001) 3 S.C.R. 534 (India)

18 We found orders published in Manupatra in CEHAT and Others $v$. Union of India and Others of the following dates: 05/04/2001, 09/19/2001, 12/11/2001, 04/30/2002, 03/31/2003, 08/04/2003, 07/07/2003, 9/10/2003.

${ }^{19}$ When we refer to State governments, we also include Union territories in that definition.

20 Order dated September 19, 2001.

21 See e.g., Order dated May 5, 2001.

22 CEHAT and others v. Union of India and others, W.P. (C) No. 301/2001, September

19, 2001. 
stakeholders involved in prior orders. ${ }^{23}$ Below are examples of some of the "directions" issued to each relevant stakeholder. Some of its directions seem to apply even after the date of the final order. After closing the case though, the Supreme Court had even less ability to ensure that any of its directions were actually complied with than when it kept the case open.

\section{Directions to the Central Government}

- To create public awareness against the practice of sex selection and sex determination.

- To implement the Act with all vigour and zeal.

Directions to the Central Supervisory Board

- $\quad$ To call for meetings at least once in six months.

- To review and monitor implementation of the Act.

- $\quad$ To call for quarterly updates from State and Union Territory (UT)

Appropriate Authorities regarding the implementation and working of the Act.

- To examine the necessity of amending the Act keeping in mind emerging technologies and difficulties in implementation of the Act.

- To lay down a code of conduct to be observed by persons working under the Act and to ensure its due publication.

- To require Medical Professional Bodies/Associations to create awareness and to ensure implementation of the Act.

\section{Directions to State Governments and UT Administrations}

- $\quad$ To appoint by Notification fully empowered Appropriate Authorities at the district and sub district levels.

- $\quad$ To appoint Advisory Committees to aid and advise Appropriate Authorities.

- To furnish a list of Appropriate Authorities in the print and electronic media.

- $\quad$ To create public awareness against the practice of sex selection and sex determination.

- To ensure that Appropriate Authorities furnish quarterly returns to the Central Supervisory Board, giving information on the implementation and working of the Act.

${ }^{23}$ CEHAT v. Union of India, 2003 SOL Case No. 547 (2003). 


\section{Directions to Appropriate Authorities}

- $\quad$ To take prompt action against any person or body that issues or causes to be issued any advertisement in violation of the Act.

- $\quad$ To take prompt action against all bodies and persons who are operating without valid Certificate of Registration under the Act.

- $\quad$ To furnish quarterly returns to the Central Supervisory Board about the implementation of the Act.

\section{Indian Parliam ent Amends the PNDT(2002)}

In examining the transcripts of various committee discussions about sex selection, it is clear that members of the Rajya Sabha, one of the two houses of Parliament, were keenly aware of the Supreme Court's orders. For example, Prema Cariappa, a Member of Parliament from Karnataka observed that "the hon'ble Supreme Court has passed an order on 4th May, 2001 directing the registration of all bodies using the ultrasound equipment, under the Pre-natal Diagnostic Techniques (Regulation and Prevention of Misuse) Act, 1994." 24 On another day, the Member of Parliament from Tamil Nadu even quoted one of the Supreme Court orders at length.

${ }^{24}$ Rajya Sabha Transcripts Dec 11, 2002 PREMA CARIAPPA from Karnataka. 
Over the course of the time the Supreme Court held jurisdiction, the Ministers of Health were often called to testify about the case. For example, on November 25, 2002, the Minister of Health and Family Welfare (Shri Raja) discussed the Supreme Court orders to State governments in great detail and specifically noted that the "the Hon'ble Supreme Court of India has been issuing directions since May 2001 to the Union of India as well as State/UTs." He also points out that implementation of the PNDT rests with the States and Union Territories.

On Dec 16, 2002, the Rajya Sabha again asked the Minster of Health and Family Welfare to report on the Supreme Court order. He provided a detailed overview of the July 10, 2002 order and indicated that the Supreme Court ordered certain states to act against clinics that were still advertising sex determination tests despite the fact that was illegal. The states indicated that 305 ultrasound machines were seized. A "National Inspection and Monitoring Committee" has been set up to "kept watch on all States and UTs," which apparently makes surprise visits to clinics.

The Lok Sabha, the other house of Parliament, also discussed the Supreme Court orders. In its $13^{\text {th }}$ session on December 20, 2002, the Minister of Health specifically noted that the "The hon. Supreme Court has further directed amending the PNDT Act" and then he went on to make specific suggestions for amendments which he said is based on the recommendations of the Central Supervisory Board that was constituted under the PNDT. Indeed, this is the entity that the Supreme Court had directed to propose amendments to the PNDT.

The Central Supervisory Board did propose amendments to the PNDT. Thereafter, the Parliament amended the PNDT, changing its title to "The Pre-Conception and Pre-Natal Diagnostic Techniques (Prohibition of Sex Selection) Act" (PCPNDT). ${ }^{25}$ The PCPNDT (among other things) increases the penalties and other regulations targeted at clinics. ${ }^{26}$ Even though the amendments were meant in part to address advancements in sex determination technology, the reality is that most people are not likely to use this technology, in vitro fertilization ("IVF"), for sex selection purposes because they are expensive. IVF together with a test to determine the sex of an embryo costs $\$ 5500$ in India. ${ }^{27}$

Medical personnel and individuals who violate the PCPNDT are subject to criminal penalties and fines. Every clinic that uses diagnostic tests that can be used for sex

25 The Pre-NatalDiagnostic Techniques (Regulation and Prevention of Misuse) Amendment Act, No. 14 of 2003, India CodE (2003).

26 The Pre-NatalDiagnostic Techniques (Regulation and Prevention of Misuse) Amendment Act, No. 14 of 2003, India Code (2003).

${ }^{27}$ IVF Cost, GLOBAL Doctor Options, http://www.globaldoctoroptions.com/ivfcost/424 (last visited Aug. 13, 2015) http://www.globaldoctoroptions.com/ivfcost $/ 424$ 
determination must register them. ${ }^{28}$ Each local jurisdiction must appoint a local officer monitor compliance with the PCPNDT. ${ }^{29}$ The PCPNDT further requires all clinics, centers, and laboratories to maintain records of all prenatal diagnostic tests they conduct in order to monitor their use. Additionally, the PCPNDT prohibits anyone from selling ultrasound machines to unregistered clinics or laboratories. ${ }^{30}$ Likewise, the PCPNDT prohibits any kind of advertising of pre-conception or prenatal sex determination. ${ }^{31}$

The PCPNDT (like the PDNT) does not limit abortion directly, but, instead limits only disclosure of information about the future sex of the child. ${ }^{32}$

\section{Mapping Sex Selection}

Before we discuss our findings regarding the impact of the Supreme Court's decision, we briefly outline the history and current state of the Indian sex ratio crisis using data from the Indian Census. Amartya Sen drew attention to the maltreatment of women by coining the phrase "missing women." 33 This created a genre of studies that use sex ratios (the number of women to men in any given society) to calculate the number of missing women. While Sen intended the category to capture the many facets of inequality women face, "missing women" is more commonly used to mean the number of aborted female fetuses.

In the 1980 s, estimates ranged from 100,000 to 220,000 "missing women" annually in India. After 2000, some believed that anywhere from 300,000 to 700,000 women were "missing" a year. ${ }^{34}$ There are large variations in these estimates due to different assumptions about the "normal" sex ratio, different mortality adjustments (including adjustments to account for reasons other than sex-selective abortion that impact imbalanced child sex ratios), and the use of different sources of data (e.g., the Indian census, the National Family Health Survey, or the Sample Registration System). ${ }^{35}$

28 The Pre-NatalDiagnostic Techniques (Regulation and Prevention of Misuse) Amendment Act, No. 14 of 2003, IndiA CoDE (2003), ch. VI (18).

${ }^{29} \mathrm{Id}$ at $\mathrm{V}(17)$.

${ }^{30} \mathrm{Id}$ at ch. II (3)(B).

${ }^{31}$ Id at ch. VII (22).

32 KiRTi Singh, U.N. POPUlation Fund (UNFPA), LAWS AND SON-PREFERENCE IN INDIA: A REALITY CHECK 58, 73 \& n.94 (2013), available at http://www.unfpa.org/sites/default/files/jahia-

news/documents/publications/2013/LawsandSonPreferenceinIndia.pdf.

33 Amartya Sen, More Than 100 Million Women Are Missing, N.Y. REV. BoOKS, Dec. 20, 1990.

${ }^{34}$ Melissa Stillm an ET Al., GutTm acher Inst., AbORTion in India: A Literature REVIEW 18 (2014), available at https://www.guttmacher.org/pubs/Abortion-India-LitReview.pdf.

35 Id. 
In India, sex ratios are calculated as the number of females for every 1000 males. We would expect to see at-birth sex ratios anywhere between 930 and 970 women to 1000 men without any parental intervention. Although most commentators blame sex-selective abortions for causing an imbalanced sex ratio, abortion is not responsible for the entire imbalance. The Guttmacher Institute report notes that ultrasounds can only reliably determine sex during the second trimester of pregnancy, but only $10-15 \%$ of all abortions are performed after the first trimester. ${ }^{36}$ The Indian census calculates only the child sex ratio, which is the ratio of girls to boy from birth to six years of ago. Postnatal neglect of young female girls can also be a reason for excess female child mortality and male-biased child sex ratios. ${ }^{37}$

The child sex ratio in India in the 2011 Census was 914, which had dropped from 927 in the 2001 Census. Graph 1-1 depicts the sex ratio of the child sex ratio since 1951 in India.

\section{Graph 1-1: Child Sex ratios in India from 1951 to 2011}

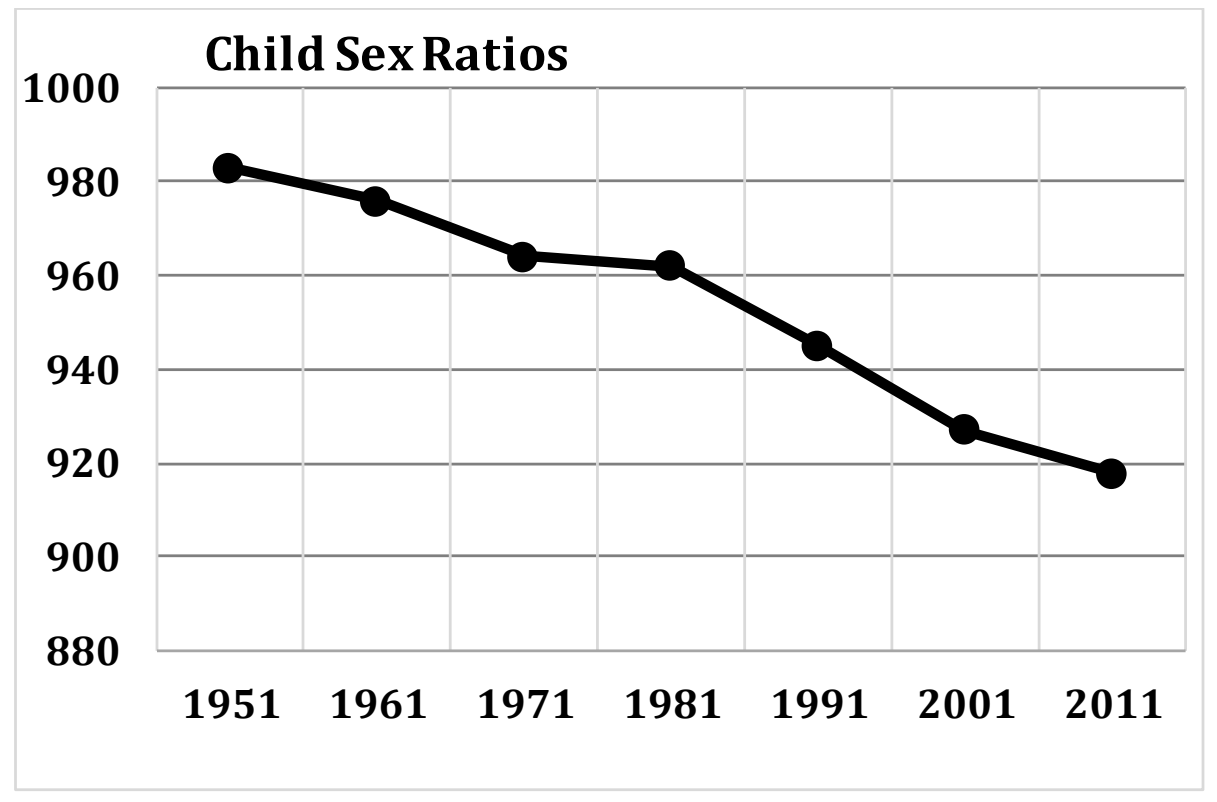

Although the popular perception is that sex selection prevails throughout all parts of the country, the reality is that there is great regional variation among Indian states and territories. According to the 2011 Indian Census, 10 states or territories had child sex

${ }^{36} \mathrm{Id}$.

37 Oster, Emily. "Proximate sources of population sex imbalance in India." Demography 46.2 (2009): 325-339. Available at

http://www.ncbi.nlm.nih.gov/pmc/articles/PMC2831281/ 
ratios at or above 950 and 19 states had sex ratios above 930. Below is a histogram showing the distribution of child sex ratios in the Indian states and territories.

Graph 1-2: Histogram of Child Sex Ratios in Indian States and Territories

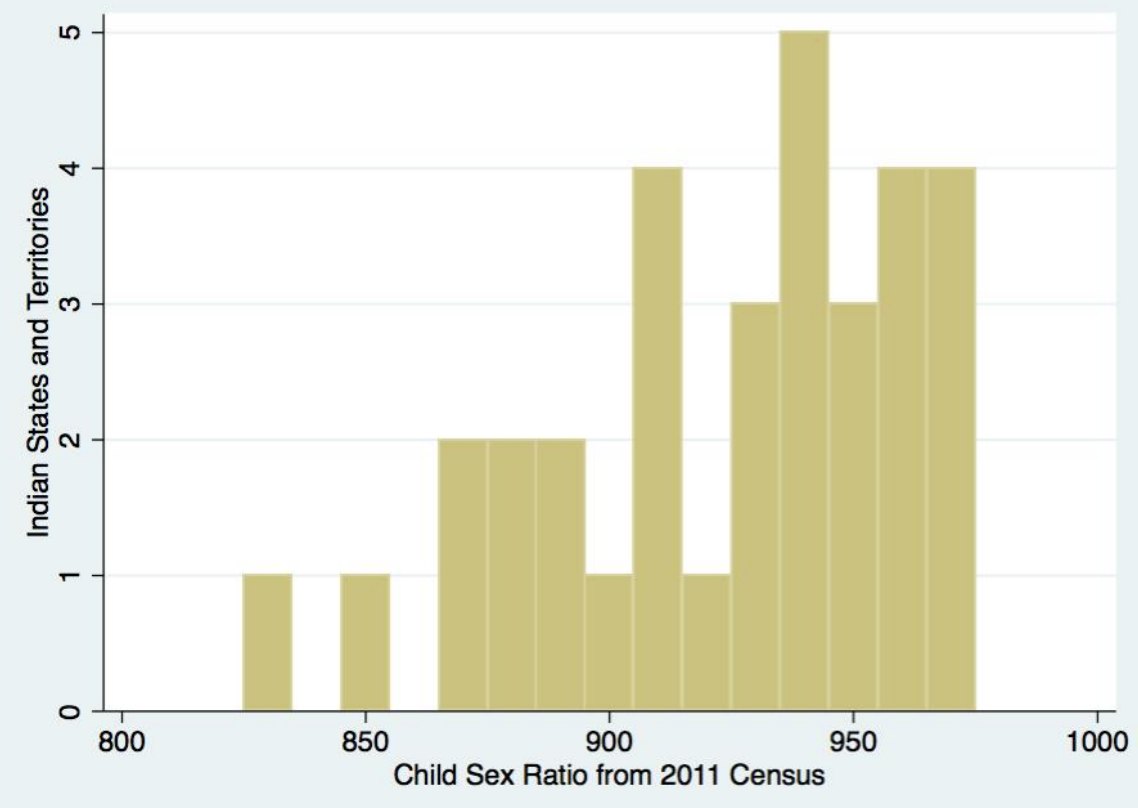


Source: Indian Census Bureau, available at http://censusindia.gov.in/2011-provresults/data_files/india/s13_sex_ratio.pdf

The child sex ratios in the states and territories have also changed over the course of 10 years. Graph 1-3 below illustrates the changes in sex ratios from the 2001 to the 2011 Indian Census. Child sex ratios improved in eight states, but none reached 950 except for Mizoram and Andaman \& Nicobar Islands (which already had sex ratios above 950 in the 2011 Indian Census). Table 1-1 in the Appendix of this Chapter lists the sex ratios in each Indian state and territory in 2001 and 2011.

Graph 1-3: Graph of Changes in Child Sex Ratio in Indian States and Territories (2001 to 2011)

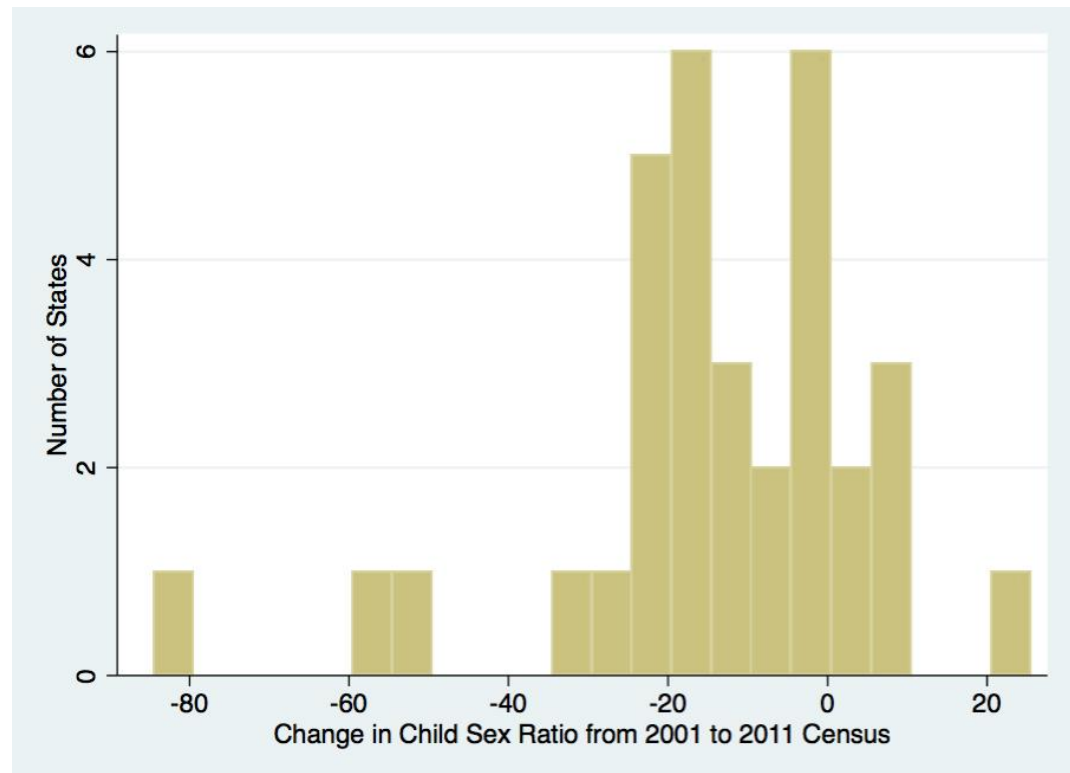


Source: Indian Census Bureau, available at http://censusindia.gov.in/2011-provresults/data_files/india/s13_sex_ratio.pdf

Having presented an overview of the current data on the child sex ratios in India, we now describe the impact of the Supreme Court's orders in the sex selection case.

\section{Measuring the Impact of the Supreme Court Judgment}

The Supreme Court's intervention helped to push the Central Supervisory Board, an institution created pursuant to the PNDT, to propose amendments to the PNDT to account for new reproductive technologies that allowed people to preselect the future sex of their child and to improve enforcement mechanisms of the law (among other things). Parliament thereafter passed amendments to the PNDT.

It is possible that the Parliament would have amended the PNDT without Supreme Court intervention. Even though we cannot prove a casual connection between the Supreme Court's intervention and amendment of the PNDT, we can more firmly conclude that the Court's intervention hastened the process of amendment. The amendments were beneficial because they closed a number of loopholes, increased penalties, and strengthened enforcement. In addition, the State governments were held to task by the Court. They were asked to file compliance reports and encouraged to punish illegal ultrasound operators. We do not have a way of determining whether States actually increased compliance efforts during or after the period that the Supreme Court kept jurisdiction over the case.

Measuring impact in terms of the ultimate goals of the advocates, the Supreme Court's intervention was not successful. The end-goal of the advocates who brought the public interest litigation in 2000 as well as the Supreme Court was to decrease the number of abortions of female fetuses. The litigants hoped that by prodding the Supreme Court, the Parliament would amend the law that banned sex determination tests and would also encourage state governments to enforce the law. Although the law was amended and perhaps implementation efforts increased, there was no improvement in the male-skewed sex ratio.

It is obvious from Graph 1-1 that the child sex ratios continued to become more maleskewed from the 2001 Indian Census to the 2011 Indian Census. While the Census measures changes over a 10 -year period, the question that still remains is whether within that 10-year period there any improvements in the number of female births. The unique data we use allows us to make observations year-by-year in regard to number of female births. We use data from two district level household surveys (DLHS) of India, DLHS-2 during 2002-2004 and DLHS-3 during 2007-2008. The DLHS are large scale nationally representative cross-sectional household surveys covering all districts of India. The surveys covered 620,107 and 720,320 households respectively. The primary focus of the surveys was on reproductive, maternal, and child health, including pregnancy and 
childbirth, access to healthcare, child nutrition, immunization, and morbidity and mortality of household members. The primary survey respondents were married women of reproductive age (15-44 old women in DLHS-2 and 15-49 year old women in DLHS3).

A household questionnaire in the DLHS collected information on the demographic and socioeconomic characteristics, including the location, caste, religion of the household, and age, sex, and educational attainment of each member. Standard of living of the household was captured through the ownership of durable assets, such as TV, radio, bicycle, and car, and housing and living condition indicators, such as the availability of toilets and kitchen, type of cooking fuel and lighting source, and the quality of building materials used. A separate questionnaire for the respondent woman collected data on a complete lifetime birth history in DLHS-2, and a truncated birth history since January 2004 in DLHS-3. Birth history data included information on the date of birth, birth order, gender, and age at death (in case the child was not alive at the time of the survey) of children. Additional information on prenatal and postnatal care, pregnancy complications and outcomes was also collected.

We examine the average annual probability of female-births among all ever born children during two decades, 1989-2008. From DLHS-2, we obtain data on children born during years 1989 to 2003, while DLHS-3 provides us childbirth data during years 2004 to 2008. The sample sizes of children born during each year, along with the average and standard deviation of the likelihood of female births is presented in Table 1. The trend in the annual average female-birth rate over time is also presented in Figure 1.

We find that the share of girls among newborn children has been consistently declining over our study period, from $48.5 \%$ in 1989 to $42.9 \%$ in 2008. In comparison, the internationally accepted normal male-to-female sex ratio (number of boys for each girl) at birth ranges between 930 and 970 girls per boys, which is equivalent to $49.2 \%-48.3 \%$ share of girls, respectively.

We would expect that the Supreme Court's efforts at pushing the states to implement the law, which commenced just after the petition was filed in 2000 , would likely see positive gains in female births only after 2002. This would give time for the states to actually implement and enforce the law and then it would take at least nine more months to see an impact on the rate of female births. However, there was a sharp decline during the period 2002-2008, which is preciously when we would expect to see the greatest impact of the Supreme Court's interventions.

Table 1: Average annual probability of female -births in India: 1989-2008

\begin{tabular}{cccc}
\hline Year & $\begin{array}{c}\text { Mean share of } \\
\text { fe male-births }\end{array}$ & $\begin{array}{c}\text { Standard } \\
\text { de viation }\end{array}$ & $\begin{array}{c}\text { Sample size } \\
\text { (number of } \\
\text { births })\end{array}$ \\
\hline 1989 & 0.485 & 0.500 & 57,176 \\
1990 & 0.479 & 0.500 & 65,615 \\
1991 & 0.480 & 0.500 & 61,873
\end{tabular}




$\begin{array}{llll}1992 & 0.476 & 0.499 & 72,728 \\ 1993 & 0.478 & 0.500 & 65,990 \\ 1994 & 0.477 & 0.499 & 74,826 \\ 1995 & 0.481 & 0.500 & 70,493 \\ 1996 & 0.479 & 0.500 & 78,077 \\ 1997 & 0.478 & 0.500 & 73,591 \\ 1998 & 0.480 & 0.500 & 80,662 \\ 1999 & 0.478 & 0.500 & 74,735 \\ 2000 & 0.480 & 0.500 & 75,324 \\ 2001 & 0.475 & 0.499 & 71,157 \\ 2002 & 0.479 & 0.500 & 55,391 \\ 2003 & 0.477 & 0.499 & 35,201 \\ 2004 & 0.460 & 0.498 & 56,801 \\ 2005 & 0.460 & 0.498 & 70,353 \\ 2006 & 0.449 & 0.497 & 73,218 \\ 2007 & 0.444 & 0.497 & 78,953 \\ 2008 & 0.429 & 0.495 & 22,055\end{array}$

Source: Data are from DLHS-2 (children born during 19989-2003) and DLHS-3 (children born during 2004-2008). Author's calculations.

Figure 1: Average annual rate of female-birth in India: 1998-2008

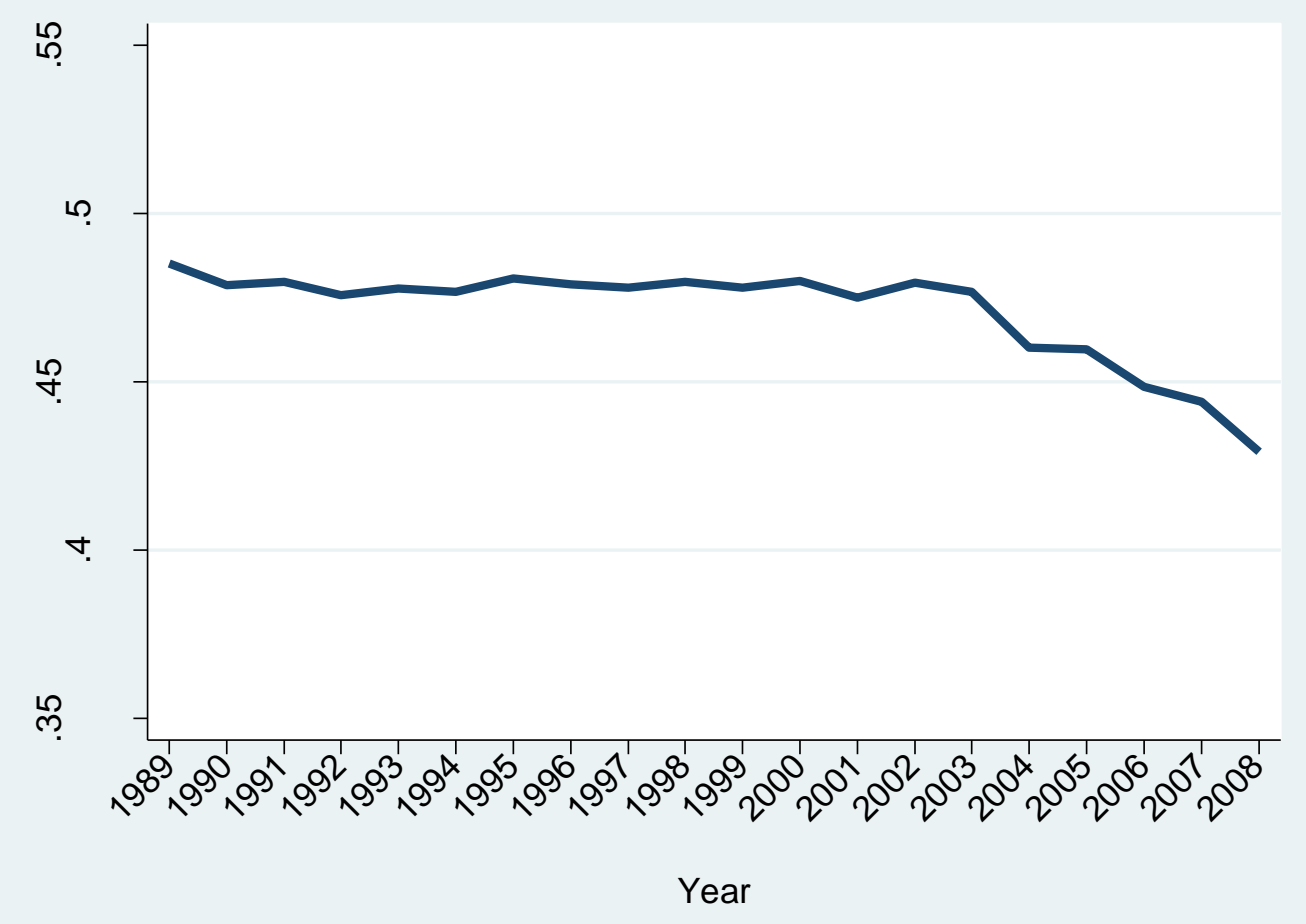

Source: Data are from DLHS-2 (children born during 1998-2004) and DLHS-3 (children born during 20042008). Author's calculations. 
Several observable and unobservable socioeconomic factors and public policies may determine the trend in female-birth probability during our study period. For example, demographic transition or changes in income levels may lead to changes in the preference for sons over daughters, ${ }^{38}$ in turn leading more sex-selective abortion of girls. We can adjust the raw time trend shown in Figure 1 by removing the effect of various observable characteristics of the household, parents, and the child in the following way.

We first create a pooled child-level dataset (for all children born during1998 to 2008) from DLHS-2 and DLHS-3. Then, a state fixed-effect linear regression of the following form is estimated:

$$
\text { Female }_{i t}=\alpha+\beta \text { State } e_{i}+\gamma X_{i t}+\epsilon_{i t}
$$

for the $i$-th child born in year $t$. The outcome variable Female Fit $_{1}=1$ if the newborn child is a girl, and 0 otherwise. State $e_{i}$ denotes a set of appropriate number of dummy variables for states, and $X_{i t}$ is a vector of background characteristics of the household, parents, and the newborn child. Included in $X_{i t}$ are the indicators of location (rural or urban), and caste (scheduled caste, scheduled tribe, or other backward classes), religion (Hindu, Muslim, or Sikh), and age and gender of the household head. Among parental and child characteristics, we include indicators of various levels of education (grades 1-5, 6-11, and 12 and above completed) of the mother and father, mother's age, and the newborn child's birth order in $X_{i t}$. We control for the standard of living of the household by first constructing a composite index of asset ownership (e.g. radio, sewing machine, TV, bicycle, car) and living condition (e.g. construction quality, availability of toilet and electricity, sources of drinking water) using principal-component method. ${ }^{39}$ The index is then divided into five quintiles and indicators of the top four quintiles are included in $X_{i t}$.

$\epsilon_{i t}$ is the error term of the regression. We cluster all standard errors at the district level. The estimated residual error of the regression, $\hat{\epsilon}$, will therefore include factors that are not incorporated in our analysis, including unobservable household and community characteristics and public policies that may affect the secular trend in the female-birth probability.

Figure 2 shows the time trend of residual probability of female-birth obtained from the regression. We find the residual probability to remain fairly stable with a very slight downward trend over our study period. Therefore, we can argue that the Supreme Court

\footnotetext{
38 Monica das Gupta \& P.N. Mari Bhat, Fertilitiy Decline and Increased Manifestation of Sex Bias in India, 51 Population Stud. 307 (1997); Mamta Murthi, Anne-Catherine \& Jean Drèze, Mortality, Fertility, and Gender Bias in India: A District-Level Analysis. 21 POPULATION\& DEV.REV. 745 (1995).

${ }^{39}$ Deon Filmer \& Lant H. Pritchett, Estimating Wealth Effects without Expenditure Dataor Tears: An Application to Educational Enrollments in States of India, 38DEMOGRAPHY 115 (2001).
} 
judgment is not associated in any improvement in the sex ratio at birth in the short to medium term.

Figure 2: Residual annual average probability of female-birth in India: 1998-2008

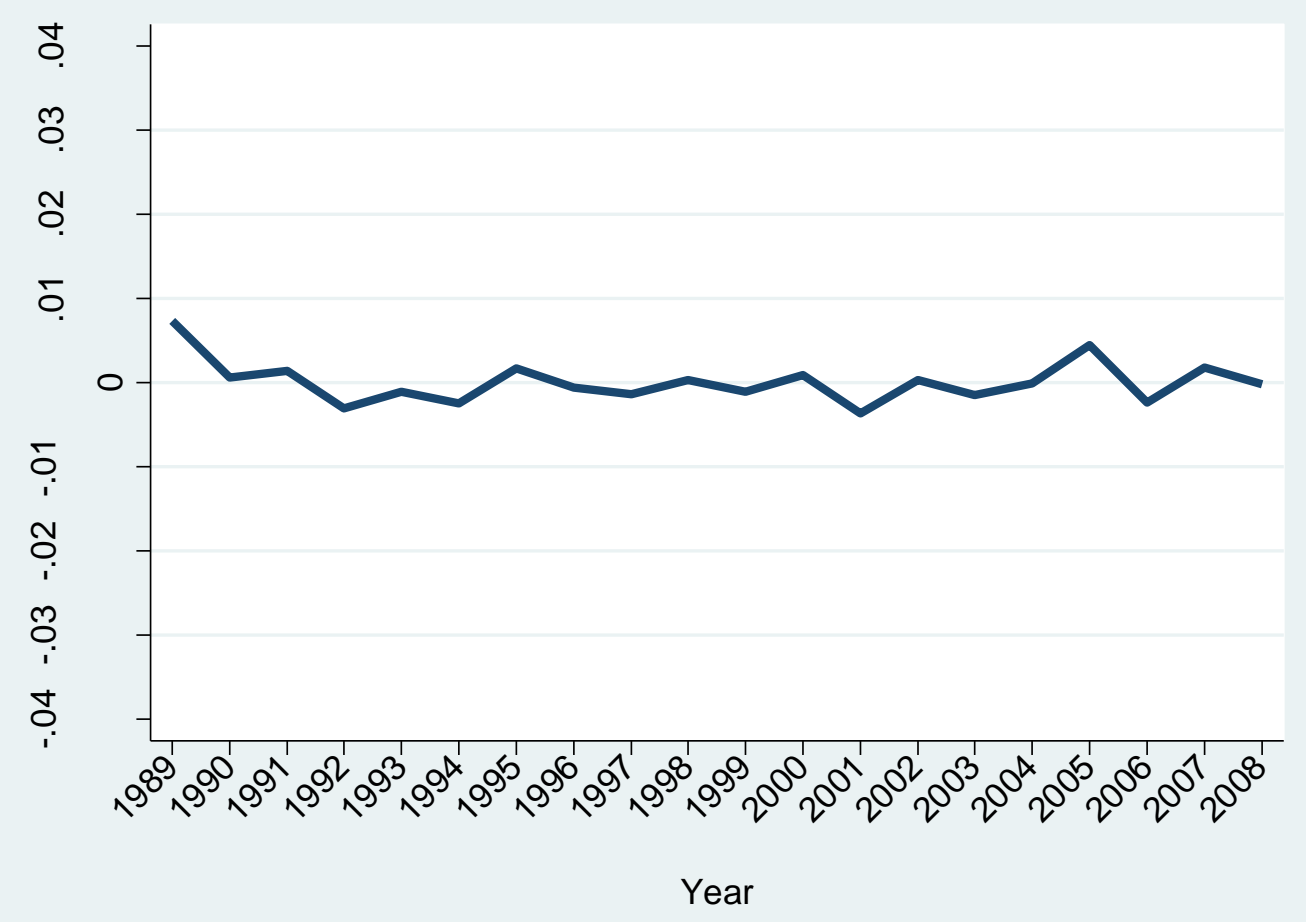


Source: Data are from DLHS-2 (children born during 1989-2004) and DLHS-3 (children born during 20042008). Residual probability is estimated from regres sion equation (1).

Even if there has been any positive effect that remains undetected in our data, it is clearly not enough to reduce the male bias in the sex ratio. Female births continued to decrease and decreased most sharply during the time we would expect the Supreme Court's efforts to have had the most impact from 2002 to 2008. Thus, examining only the sex ratio, we are left with the impression that at least in regard to the practice of sex-selective abortion, the Supreme Court's intervention did little to curb the behavior it wanted to prevent.

\section{Why the Supreme Court's Intervention Did not Normalize Sex Ratios?}

As noted above, the Supreme Court's intervention and indeed even the Parliament's intervention was not successful in normalizing the sex ratios. Quite the contrary, the number of female births as compared to all births decreased. Of course, we cannot rule out the possibility that the number of female births could be even lower had the Supreme Court not intervened. ${ }^{40}$ In this section, we discuss some of the factors that may help explain why the Supreme Court's order and even an act of Parliament could not prevent the women who selectively aborted female fetuses from doing so. First, the desire of families to have at least one son is a deep-seated cultural norm in many parts of India. This view combined with changing macro-economic factors that lead to a desire for smaller families often pushes people to elect selective abortion. People in society are more likely to resist laws that go against cultural norms than laws that support the mainstream view. Second, the behavior that the government has made illegal (e.g., disclosing the future sex of a fetus) is difficult to regulate. It can occur within the privacy of a doctor's office and people can also gain this information through non-licensed operators of ultrasound machines.

\section{Families Desire Both At least one Son and Smaller Family Sizes}

Both in the popular imagination and in scholarly work, "culture" is often used to explain the widespread practice of sex-selective abortion. ${ }^{41}$ This is often disaggregated into a list of evils in society that essentially place women in an inferior position to men. First,

\footnotetext{
${ }^{40}$ Indeed, one of the co-authors (Nandi) has found in another article that the sex ratios in one state (i.e., Maharashtra) that banned sex determination tests before any other state were less male-skewed than the sex ratios in neighboring states that had not adopted bans.

Nandi, Arindam, and Anil B. Deolalikar. "Does a legal ban on sex-selective abortions improve child sex ratios? Evidence from a policy change in India." Journal of Development Economics 103 (2013): 216-228. Available at http://dx.doi.org/10.1016/j.jdeveco.2013.02.007. See also Nandi Arindam (2014) "The Unintended Effects of a Ban on Sex-Selective Abortion on Infant Mortality: Evidence from India". Oxford Development Studies. 43(2015):466-482. Available at http://dx.doi.org/10.1080/13600818.2014.973390

${ }^{41}$ MARA HVISTENDAHL, UnNATURAL SELECTION 71-72 (2011).
} 
patrilocal marriages, where a couple settles into the husband's family's home, are the norm and are often used to explain "son-preference." As a result of this custom, a daughter is thought to be paraya dhan (someone else's wealth). Sons are the ones who are assumed to be breadwinners for the families. A lack of a pension system in India leads parents to rely on the son to provide financial support during old age. On the other hand, there are strong norms against families taking money or any support from a married daughter. To the extent a woman earns an income outside of her household, she will often be expected to keep her earnings within the husband's family. For wealthier families, they desire sons because they do not want to share their wealth with daughters who will leave the natal home in the patrilocal system.

Second, dowry is another explanation for sex selection, and this flows directly from the British colonial accounts. Indeed, this factor still remains one of the most cited explanation for sex selection. Although dowry is prohibited under the Dowry Prohibition Act of 1961, the practice continues today. ${ }^{42}$ As a result, when a woman gets married, her parents often have to pay money (sometimes large sums in relation to their income) to the groom's family. For poor parents, having to provide a dowry when a daughter marries is often economically challenging.

Third, for wealthier families, while dowry may not be as much of a burden, parents may desire sons to perpetuate their family name and the sons will be the ones that parents leave their money to. Fourth, one Hindu religious tradition is often attributed as a cause for sex selection in favor of boys - many Hindus believe that only sons should light the funeral pyre of their parents. Others believe that moksha (liberation from rebirth or reincarnation) is only possible through their sons. ${ }^{43}$

Fifth, another factor often cited is the low status of women, which occurs, among other things, because they lack opportunities for paid work (and their unpaid work is not valued) and generally do not own property. In many places, women do not have economic opportunities or are not permitted to work outside of the home. Although inheritance laws have been reformed, a daughter is often expected to give up her rights to her parents' property in favor of her brothers. ${ }^{44}$ An Indian government agency has pointed out that in India women own just 10.9 percent of the land. ${ }^{45}$ This is because even

${ }^{42}$ Mallika Kaur Sarkaria, Comment, Lessons from Punjab's "Missing Girls": Toward a Global Feminist Perspective on "Choice” in Abortion, 97 CALIF. L. REV. 905, 910-11 (2009).

43 See Rita Patel, The Practice of Sex Selective Abortion in India: May You Be the Mother of a Hundred Sons, THECENTER FOR GLOBAL INITIATIVES 7 (1996), available at http://cgi.unc.edu/uploads/media_ite ms/the-practice-of-sex-selective-abortion-in-indiamay-you-be-the-mother-of-a-hundre d-sons.original.pdf.

44 See, e.g., Ashok Sircar, Emerging Voices: Ashok Sircar on Women 's Right to Inherit Land in India, LANDESA (June 12, 2013), http://www.landesa.org/emerging-voicesashok-sircar-womens-right-inherit-land-india-blog/. 45 UN Women Expert Group Meeting on Enabling rural women's economic empowerment: institutions, opportunities and participation, Accra, Ghana, Sept. 20-23, 
when they have a right on paper to inherit property, this right gets subverted in a variety of ways. Members of their natal family including brothers are thus able to persuade them or coerce them to relinquish their share in the family property. ${ }^{46}$

All of these factors are summarized in the literature as follows: Girls are an economic liability to a family, while boys are economic assets. Technology facilitates people's desires to have sons by allowing them to determine the sex of the fetus and abort it if it is a girl.

However, a more nuanced interpretation of the data suggests that Indian people by and large do not have an aversion to having daughters, but want to have at least one son. Birth parity studies from India show that the sex ratio of the first birth of Indian children is skewed in favor of males, but gets progressively worse at second and third parities for parents who have no prior sons. In analyzing a survey of over 1 million households in India conducted in 1998, Prabhat Jha and his co-authors found that the sex ratio for the first child is 871 females to 1000 males (recall that the standard range is considered to be from 930 to 970 females for every 1000 males). ${ }^{47}$ But in the second birth parity for parents with no prior son, the sex ratio was 759 per 1000 males; and the ratio decreased in the third birth parity to 719 per 1000 males for parents with no prior sons. ${ }^{48}$ Thus, a great proportion of parents who already have one or two daughters and have no sons are intervening to ensure the birth of a son, whereas a fewer proportion of parents are intervening at the first births (and are willing to have a daughter).

Qualitative studies by Tulsi Patel confirm this view. She states that "female foeticide is not approved and/or practised for the first female foetus." 49 Thus, just because sonpreference may be widespread, it does not also mean that "daughter-aversion" is also widespread. ${ }^{50}$ Survey results also support the view that the two-child household is the

2011, Women's Access to Land: An Asian Perspective, 12, tbl. 1, U.N. Doc.

EGM/RW/2011/EP.3 (Sept. 2011), available at

http://www.un.org/womenwatch/daw/csw/csw56/egm/Rao-EP-3-EGM-RW30Sep-2011.pdf (paper prepared by Nitya Rao).

46 KiRTi Singh, U.N. POPULATION Fund (UNFPA), LAWS AND SON-PREFERENCE IN INDIA: A REALITY CHECK 51 (2013), available at

http://www.unfpa.org/sites/default/files/jahia-

news/documents/publications/2013/LawsandSonPreferenceinIndia.pdf.

47 Prabhat Jha et al., Low Male-to-Female Sex Ratio of Children Born in India: National Survey of 1.1 Million Households, 367 THE LANCET 211, 214 (2006).

48 Id.

49 Tulsi Patel, The Mindset behind Eliminating the Female Foetus, in SEX-SELECTIVE ABORTION IN INDIA, GENDER, SOCIETY AND NEW REPRODUCTIVE TECHNOLOGIES 135, 143 (Tulsi Patel ed., 2007).

${ }^{50}$ Navtej K. Purewal also points out that much research on son preference also makes assumptions about why people act certain ways on the basis of macro-trend. NAVTEJ K. Purewal, Son PrefERENCE: SEx Selection, Gender ANd Culture in South Asia 14 16 (2010). 
accepted norm and that there is no aversion to having at least one daughter. The Lawyers Collective surveyed 168 households across Delhi ${ }^{51}$ and found that an overwhelming majority of women (79\%) said that two would be the ideal number of children. ${ }^{52}$ While $60 \%$ of the women said that one male child was ideal, the same percentage said that one female child is ideal. Taken together, it appears that for the women surveyed, the ideal family is two children: one boy and one girl. This "micro-study" also found that parents who were married for less than five years had sex ratios that were female-skewed, and these sex ratios became more male-skewed as their time of marriage increased. This again supports the view that parents are willing to have girls, but want to have at least one son.

In Jha's study, we see that a very small number of parents with one or two boy children may actually be selecting for girls. Jha's study finds that the sex ratio of the second child of mothers who have one prior boy is 1102 females per 1000 males, and the sex ratio of the third child of mothers who have two prior boys is $1176 .{ }^{53}$ These sex ratios are slightly female-skewed (they are above the standard range of 930-970 females to 1,000 males). Yet, the proportion of parents with boy children that practice female-biased sex selection is much lower than the proportion of parents with girl children that practice male-biased sex selection.

A new and growing desire of people to have small families when taken together with the desire to have at least one son leads some women to selectively terminate their pregnancies. ${ }^{54}$ The United Nations Population Division estimated that the fertility rate in the 1950s was 5.9 children per woman in India, not as high as in many other developing countries at the time where the average was often seven children or more. ${ }^{55}$ By 2009 , fertility in India had declined to 2.6 children per woman, less than half the rate of the early 1950s. There are a host of reasons for the desire for smaller family sizes. Some argue that as there is a reduction in agrarian modes of production (where the labor of

\footnotetext{
51 INDIRA JAISING ET AL., From THE ABNORM AL TO THENORMAL:PREVENTING SEX SELECTIVE ABORTIONS THROUGH THELAW 108 (2007), available at http://www.lawyerscollective.org/publications/abnormal-normal-preventing-sexselective-abortions-law.html.

52 InDIRA JAISING ET AL., From THE ABnORM AL TO THE NORMAL:PREVENTING SEX SELECTIVE AbORTIONS THROUGH THELAW 117 (2007), available at http://www.lawyerscollective.org/publications/abnormal-normal-preventing-sexselective-abortions-law.html.

53 Prabhat Jha et al., Low Male-to-Female Sex Ratio of Children Born in India: National Survey of 1.1 Million Households, 367 THE LANCET 211, 211 (2006).

54 ChristopheZ. Guilmoto, UNFPA Asia And the Pacific Regional OfFice, SeX IMBALANCES AT BIRTH:CURRENT TRENDS, CONSEQUENCES AND POLICY IMPLICATIONS 10 (2012), available at http//www.unfpa.org/publications/sex-imbalances-birth. 55 Carl Haub \& James Gribble, Population Reference Bureau, Population BULLETIN: THE WORLD AT 7 BILLION 9 (2011), available at http://www.prb.org/pdf11/world-at-7-billion.pdf.
} 
children might have been important), people are having fewer children. ${ }^{56}$ In urban areas, increasing prices and cost of living influence people to have smaller families. ${ }^{57}$

Another reason for the changing family size norms has to do with the governmental policies in India. While most people know about China's one-child policy (which it recently announced it will change), ${ }^{58}$ few are aware of the coercive policies adopted by Indian state governments to enforce a two-child norm model. In pursuit of the goal of smaller families, certain states have adopted prohibitions barring people with more than two children from holding posts in local governing bodies. Currently, the two-child norm is a part of the population policies in Uttar Pradesh, Madhya Pradesh, Rajasthan, and Maharashtra. 59

The Indian Supreme Court has found that the two-child norm in the Haryana Panchayati Raj Act, 1994 did not violate the constitution. The Court held that the "disqualification on the right to contest an election by having more than two living children does not contravene any fundamental right nor does it cross the limits of reasonability. Rather it is a disqualification conceptually devised in the national interest." 60 Thus, a person's right to have children can be restricted in favor of the larger goal of population control. In upholding two-child norm policies, the Supreme Court may have unintentionally undermined efforts to curb sex selection. By forcing families to have no more than two children, some may sex select to ensure that one of their children is a male.

\section{Challenges in Enforcing the PCPNDT}

There are several reasons for the failure of the PCPNDT to reduce sex-selective abortions. First, it is inherently difficult to enforce the PCPNDT. Ultrasound technology is not completely banned under the law and on the contrary, they are now a common part of pre-natal care practices. They can be used to detect the sex of the fetus. It is difficult to prevent medical professionals from conveying the sex of fetuses in the privacy of their patient rooms. Indeed, medical professionals who convey the sex of the fetus do so in coded terms.

\footnotetext{
${ }^{56}$ Mary John, U.N. Population Fund (UNFPA), Sex Ratios And Gender Biased SEX SELECTION HiSTORY, DEBATES AND FUTUREDIRECTIONS 42-43 (2014), available at http:/asiapacific.unfpa.org/webdav/s ite/asiapac if ic/shared/Publications/2014/Sex-Ratiosand-Gender-Biased-Sex-Selection.pdf.

${ }^{57}$ Ravinder Kaur, Dispensable Daughters and Bachelor Sons: Sex Discrimination in North India, 43 ECON. \& POL. WKLY. 109, 114 (2008).

58 See China Reforms: One-Child Policy to be Relaxed, BBC, Nov. 15, 2013.

59 KiRTi Singh, U.N. POPULATION FUnd (UNFPA), LAWS AND SON-PREFERENCE IN INDIA: A REALITY CHECK 80 (2013), available at http://www.unfpa.org/sites/default/files/jahianews/documents/publications/2013/LawsandSonPreferenceinI ndia.pdf. 60 Javed v. State of Haryana, A.I.R. 2003 S.C. 3057 (India).
} 
Additionally, while licensed medical professionals using registered ultrasound equipment can illegally disclose information about the future sex of the fetus, there are also unlicensed people using unregistered ultrasounds for the purposes of sex determination. A robust black market for sex determination and sex-selective abortions has developed.

We have presented two potential factors that explain why it is difficult for the Supreme Court and even for an act of Parliament to prohibit sex-selective termination of pregnancies. The demand for reducing family size while at the same time having a male heir is strong in parts of India. At the same time, the illegal activities occur in private and the law is easy to evade - it requires only access to an ultrasound machine.

\section{Conclusion}

The child sex ratio became starkly more male-skewed starting in the 1980s in India. Technology that gave pregnant women information about the sex of their fetuses became widespread. A desire by many parents to have at least one male child, while at the same time wanting to have a fewer number of children (than their predecessors) all led to many women to abort female fetuses. In 1994, Parliament reacted by (among other things) prohibiting medical professionals from revealing to pregnant women the sex of their fetuses. This law to prevent sex determination went into effect in 1996. Four years later, a group of litigants brought a public interest litigation to the Supreme Court arguing that the State governments had to yet to implement the law by appointing authorities to enforce it. The Supreme Court kept jurisdiction for three years in this case and in those three years, a panel of three judges led primarily by Justice Shah focused attention of State and Union governments to the problem of the widespread selective abortion of female fetuses.

In a dialogue that lasted nearly three years with the State governments and the Union government, the Supreme Court hauled into its courtroom in New Delhi representatives from State governments and Union government to question them about enforcement of the legislation. The Supreme Court also demanded that the State government representatives file compliance reports and called out by name those governments that had failed to file such reports on a timely basis. In addition, the Supreme Court ordered the body that was appointed pursuant to the legislation that banned sex determination tests to consider amendments to the law that would places restrictions on using newly emerging technology for the purposes of preselecting the sex of a child.

During the time period that the Supreme Court kept jurisdiction in this case, transcripts of discussions in the Rajya Sabha reveal an acute sense of awareness of the orders of the Supreme Court. Indeed, amendments were drafted by the Central Supervisory Board and were eventually enacted by the Parliament. Thus, the Supreme Court's prodding certainly hastened the process of strengthening the legislation aimed atcurbing sexselective abortions.

However, an analysis of unique annual sex ratio data over from 1998 to 2008 reveals that 
the Court decision was not associated with any improvements in the relative number of female births. On the contrary, there was a sharp decline in the number of females born exactly when we would expect the Supreme Court's interventions to have had the most impact. Indeed, even the legislation did not work to prevent sex ratios from becoming more male-skewed. This is because it is very difficult to regulate activity that occurs within the privacy of a medical professional's office, to prevent illegal operators from providing a service that is highly in demand, and to change the views of people who believe that their families will not be complete without at least one male child. Thus, the PIL was successful in pushing for law reform, but was not able to impact social change. 


\section{References}

CEHAT and Ors. v. Union of India and Ors. . 2001. W.P. (C) No. 301/2000 (The

Supreme Court of India, September 19).

CEHAT and Ors. v. Union of India and Ors. . 2001. W.P. (C) No. 301/2000 (The

Supreme Court of India, December 11).

CEHAT and Ors. v. Union of India and Ors. . 2003. Writ Petition (Civil) No. 301 of 2000 (The Supreme Court of India, September 10).

CEHAT and Ors. v. Union of India and Ors. . 2000. Writ Petition (Civil) No. 301 of 2000

(The Supreme Court of India, May 4).

CEHAT and Ors. v. Union of India and Ors. . 2002. Writ Petition (Civil) No. 301 of 2000 (The Supreme Court of India, April 30).

CEHAT and Ors. v. Union of India and Ors. . 2003. Writ Petition (Civil) No. 301 of 2000 (The Supreme Court of India, March 31).

CEHAT and Ors. v. Union of India and Ors. . 2003. Writ Petition (Civil) No. 301 of 2000 (The Supreme Court of India, August 8).

CEHAT and Ors. v. Union of India and Ors. . 2003. W.P. (C) No. 301 of 2000 and W.P. (C) No. 339/2002 (The Supreme Court of India, July 7).

Census Organization of India. 2011. "Sex Ratio in India." Census 2011 India. Accessed August 24, 2018. https://www.census2011.co.in/sexratio.php.

Centre for Enquiry into Health and Allied Themes (CEHAT) v. Union of India. 2003. Writ Petition (civil) 301 of 2000 (Supreme Court of India, September 10).

Filmer, Deon, and Lant H. Pritchett. 2001. "Estimating Wealth Effects Without Expenditure Data-or Tears: An Application to Educational Enrollments in States of India." Demography, Vol. 38, No. 1 115-132.

Global Doctor Options. n.d. Accessed August 13, 2015. http://www.globaldoctoroptions.com/ivf-cost/424.

Guilmoto, Christophe Z. 2007. "Characteristics of Sex-Ratio Imbalance in India, and Future Scenarios." October 29-31. Accessed August 24, 2018. https://www.unfpa.org/sites/default/files/resource-pdf/india_0.pdf.

-. 2012. Sex Imbalances at Birth: Current Trends, Consequences and Policy Implications. UNFPA Asia and Pacific Regional Office.

Gupta, Monica Das, and P.N. Mari Bhat. 1997. "Fertillity Decline and Increased Manifestation of Sex Bias in India." Population Studies, Vol. 51, No. 3 307-315.

Hatton, Celia. 2013. China Reforms: One-Child Policy to be Relaxed. Beijing , November 15.

Haub, Carl, and James Gribble. 2011. "The World at 7 Billion." Population Bulletin, Vol. 66, No. 2.

Hvistendahl, Mara. 2011. Unnatural Selection: Choosing Boys Over Girls, and the Consequences of a World Full of Men. New York: World Affairs.

Indira Jaising, ed. 2004. Pre-Conception and Pre-Natal Diagnostic Techniques Act: A User's Guide to the Law. New Delhi: Universal Law Publishing .

Jaising, Indira, C. Sathyamala, and Asmita Basu. 2007. From the Abnormal to the Normal: Preventing Sex Selection Abortions Through the Law. New Delhi: Lawyers Collective. 
Javed v. State of Haryana. 2003. Writ Petition (Civil) 302 of 2001 (Supreme Court of India, July 30).

Jha, Prabhat, Rajesh Kumar, Priya Vasa, Neeraj Dhingra, Deva Thiruchelvam, and Rahim Moineddin. 2006. "Low Male-to-Female Sex Ratio of Children Born in India: National Survey of 1.1 Million Households." The Lancet, Vol.367, No. 9506 211-218.

John, Mary. 2014. "Sex Ratios and Gender Biased Sex Selection." Accessed August 24, 2018. https://asiapacific.unfpa.org/sites/default/files/pub-pdf/Sex-Ratiosand-Gender-Biased-Sex-Selection.pdf.

Kalantry, Sital. 2013. "Sex Selection in the United States and India: A Contextualist Feminist Approach." UCLA Journal of International Law and Foreign Affairs 61-85.

Kaur, Ravinder. 2008. "Dispensable Daughters and Bachelor Sons: Sex Discrimination in North India." Economic and Political Weekly, Vol. 43, No.30 109-114.

Murthi, Mamta, Anne-Catherine Guio, and Jean Drèze. 1995. "Mortality, Fertility, and Gender-Bias in India: A District-Level Analysis." Population and Development Review, Vol.21, No. 4 745-782.

Nanda, Bijayalaxmi. 2006. "Campaign Against Female Foeticide: Perspectives, Strategies and Experiences." In Sex-Selective Abortion in India: Gender, Society and New Reproductive Technologies, by ed. Tulsi Patel. SAGE Publications, India.

Nandi, Arindam. 2015. "The Unintended Effects of a Ban on Sex-Selective Abortion on Infant Mortality: Evidence from India." Oxford DevelopmentStudies, Vol. 43, No. 4 466-482.

Nandi, Arindam, and Anil B. Deolalikar. 2013. "Does a Legal Ban on Sex-Selective Abortions Improve Child Sex Ratios." Journal of Economic Development, 103 216-228.

Oster, Emily. 2009. Proximate Sources of Population Sex Imbalance in India. Accessed August 24, 2018. http://www.ncbi.nlm.nih.gov/pmc/articles/PMC2831281/

Patel, Rita. 1996. "You May be the Mother of a Hundred Sons: The Practice of Sex Selective Abortion in India." Carolina Papers in International Health and Development, Vol. 3, No. 1.

Purewal, Navtej K. 2010. Son Preference: Sex Selection, Gender and Culture in South Asia. Berg.

2002. "Rajya Sabha, Synopsis of Debates." December 11. Accessed August 2018. http://164.100.47.5/new synopsis1/Englishsessionno/197/11122002.htm.

Rao, Nitya. 2011. Women's Access to Land: An Asian Perspective. September 20-23. Accessed August 25, 2018. http://www.un.org/womenwatch/daw/csw/csw56/egm/Rao-EP-3-EGMRW-30Sep-2011.pdf.

Sarkaria, Mallika Kaur. 2009. "Lessons From Punjab's Missing Girls: Toward a Global Feminist Perspective on Choice in Abortion." Califonia Law Review, Vol. 97, No. 3. 
Sen, Amartya. 1990. More Than 100 Million Women are Missing. December 20. Accessed August 24, 2018.

https://www.nybooks.com/articles/1990/12/20/more-than-100-millionwomen-are-missing/.

Singh, Kirti. 2013. "Laws and Son Preference in India: A Reality Check." August. Accessed August 24, 2018. https://www.unfpa.org/sites/default/files/jahianews/documents/publications/2013/LawsandSonPreferenceinIndia.pdf.

Sircar, Ashok. 2013. Emerging Voices: Ashok Sircar on Women's Right to Inherit Land in India. June 12. Accessed August 25, 2018.

http://www.landesa.org/emerging-voices-ashok-sircar-womens-rightinherit-land-india-blog/.

Stillman, Melissa, Jennifer J. Frost, Susheela Singh, Ann M. Moore, and Shveta Kalyanwala. 2014. Abortion in India: A Literature Review. December. Accessed August 24, 2018. https://www.guttmacher.org/sites/default/files/report_pdf/abortion-indialit-review.pdf.

The Economist. 2003. Missing Sisters. Rohtak, April 17.

2003. "The Pre-Natal Diagnostic Techniques (Regulation and Prevention of Misuse) Amendment Act, No. 14 of 2003, India Code, Chapter II (3)(B)."

2003. "The Pre-Natal Diagnostic Techniques (Regulation and Prevention of Misuse) Amendment Act, No. 14 of 2003, India Code, Chapter V (17)."

2003. "The Pre-Natal Diagnostic Techniques (Regulation and Prevention of Misuse) Amendment Act, No. 14 of 2003, India Code, Chapter VII (22)."

2003. "The Pre-Natal Diagnostic Techniques (Regulation and Prevention of Misuse), Amendment Act, No. 14 of 2003, India Code."

2003. "The Pre-Natal Diagnostic Techniques (Regulation and Prevention of Misuse)Amendment Act, No. 14 of 2003, India Code, Chapter VI (18)."

Tulsi Patel, ed. 2007. "The Mindset Behind Eliminating the Female Foetus." In SexSelective Abortion in India: Gender, Society and New Reproductive Technologies, by ed. Tulsi Patel, 135-143. SAGE Publications India.

Vinod, Hrishikesh D. 2013. "Newborn Sex Selection and India's Overpopulation Problem." Modern Economy 102-108. 